INCOME INEQUALITY IN CAPITALIST DEMOCRACIES 


\section{INCOME INEQUALITY}

$\mathbf{I N}$

\section{CAPITALIST DEMOCRACIES}

THE INTERPLAY OF VALUES AND INSTITUTIONS

Vicki L. Birchfield

The Pennsylvania State University Press University Park, Pennsylvania 


\section{Library of Congress Cataloging-in-Publication Data}

\section{Birchfield, Vicki L., I965-}

Income inequality in capitalist democracies : the interplay of values and institutions /

Vicki L. Birchfield.

p. $\quad \mathrm{cm}$.

Includes bibliographical references and index.

Summary: "Examines patterns of income inequality among I6 advanced democracies from the mid-I970s to the early 2000 and explains why some societies have a large and growing divide between the rich and the poor while others, facing similar global economic pressures, maintain more egalitarian income distributions"-Provided by publisher. ISBN 978-0-27I-03440-9 (cloth : alk. paper)

I. Income distribution-Developed countries.

2. Capitalism-Developed countries.

3. Equality-Developed countries.

4. Democracy-Economic aspects.

5. Political culture-Developed countries.

I. Title.

$$
\begin{gathered}
\mathrm{HC}_{79 . \mathrm{I}_{5} \mathrm{~B}_{5} 6} 2 \mathrm{OO} 9 \\
339.2-\mathrm{dc} 22 \\
2008030446
\end{gathered}
$$

\section{Copyright (C) 2008}

The Pennsylvania State University

All rights reserved

Printed in the United States of America

Published by

The Pennsylvania State University Press,

University Park, PA I6802-I003

The Pennsylvania State University Press is a member of the Association of American University Presses.

It is the policy of The Pennsylvania State University Press to use acid-free paper. Publications on uncoated stock satisfy the minimum requirements of American

National Standard for Information Sciences-

Permanence of Paper for Printed Library Material, ANSI Z39.48-I992. 